\title{
Microplastic Pollution in Urban Lake Phewa, Nepal: The First Report on Abundance and Composition in Surface Water of Lake in Different Seasons
}

\section{Rajeshwori Malla-Pradhan}

Environmental Assessment and Technology for Hazardous Waste Management Research Center Thitipone Suwunwong

Mae Fah Luang University

Khamphe Phoungthong ( $\nabla$ khamphe.p@psu.ac.th )

Prince of Songkla University https://orcid.org/0000-0003-4218-1439

Tista Prasai Joshi

Nepal Academy of Science and Technology

Bijay Lal Pradhan

Tribhuvan University

\section{Research Article}

Keywords: microplastic, lake, surface water, abundance, emerging, Phewa.

Posted Date: November 1st, 2021

DOl: https://doi.org/10.21203/rs.3.rs-972278/v1

License: (c) (i) This work is licensed under a Creative Commons Attribution 4.0 International License. Read Full License

Version of Record: A version of this preprint was published at Environmental Science and Pollution Research on February 3rd, 2022. See the published version at https://doi.org/10.1007/s11356-02118301-9. 


\section{Abstract}

Microplastics are man-made pollutants which have been detected in surface water and groundwater. Research on microplastic concentration in aquatic environment is an emerging field for developing countries. Nepal despite having rich water resources no information regarding microplastic in freshwater system is available. Therefore, this study investigate the presence and abundance of microplastic in lake surface water of Phewa Lake, the second largest lake of the country. A total of 16 sampling locations were selected for surface water sample to cover the area of $5.72 \mathrm{~km}^{2}$. The average concentration of microplastic for surface water was $2.96 \pm 1.83$ particles/L for winter season and $1.51 \pm 0.62$ particles/L for rainy season. Significance difference in microplastic concentration were observed in two different seasons. Fibers was the commonly found microplastic type in lake water and transparent as the dominant color for the two seasons. Almost all the detected microplastic were found to be $<1 \mathrm{~mm}$ in size. Polymer identification was not possible due to small size of microplastic and unavailability of advanced technique. Phewa Lake, the heart of Pokhara is an important tourist destination so proper waste disposal plan can only maintain the lake's beauty from further deterioration.

\section{Introduction}

COVID-19 pandemic has emphasized the essential role of plastic in modern society especially in healthcare sector and public health safety (Parashar \& Hait, 2021). As plastics are lightweight, flexible and durable, global plastic production has increased drastically to 368 million tons in 2019 (Plastics Europe, 2020) and by 2050 it is predicted that around 12000 metric tons of plastic debris will end up in dumping ground and in the surrounding environment (Geyer et al., 2017). With the widespread indiscriminate use of plastic products and improper disposal of plastic litter (Silva et al., 2020) during COVID-19 pandemic it has become a global and emerging pollution crisis that must be addressed by powerful and effective plan of action (United Nations Environmental Program, 2021). Recent research predicted that around 14.4 million tons of microplastic have made its way into the world's ocean floor Barrett et al. (2020).

Microplastic are plastic fragments with a diameter $<5 \mathrm{~mm}$ as defined by U.S. National Oceanic and Atmospheric Administration in 2008 (Betts, 2008). In the natural environment, microplastic are released as primary or secondary microplastic. Primary microplastic are discharged into the environment in their original form which may be from washing of clothes and as microbeads which are used in beauty and personal care products. Likewise, secondary microplastic are formed by the fragmentation of macroplastic items which may be generated from the weathering of plastic debris or disintegration of car tire (UNEP, 2018). Microplastic are ubiquitous in the aquatic environment. This is of increasing concern as it is associated with various ecotoxicological effects (Akdogan \& Guven, 2019) which includes reduction in food intake (Cole et al., 2015; Watts et al., 2015) decline in reproductive capacity (Au et al., 2015; Sussarellu et al., 2016), growth delay (Au et al., 2015; Watts et al., 2015), and enzyme alteration (Avio et al., 2015; Gambardella et al., 2017; Jeong et al., 2017). 
Likewise, Green (2016) demonstrated that when benthic fauna was exposed continuously to a higher concentration of microplastic, it decreased the overall abundance of benthic assemblage structure and triggered the species accumulation. Similarly, microplastic are medium for transferring toxic chemicals to the biota and other contaminants into the aquatic ecosystem (Brennecke et al., 2016; Koelmans et al., 2019). Microplastic enter the freshwater environment through domestic wastewater effluent (Browne et al., 2011), runoff from agricultural lands and overflow of drains during storm or rain event (Eriksen et al., 2013; Galgani et al., 2015), factory spillage (Gasperi et al., 2014) and atmospheric fallout (Allen et al., 2019; Negrete Velasco et al., 2020). Microplastic is an emerging pollutant which has been intensely studied in marine environment (Thompson et al., 2004), but recently only freshwater studies have received scientists attention (Campanale et al., 2020). Freshwater bodies act as a carrier of microplastic and transport network of microplastic to the marine environment (Jiang et al., 2018). The country Nepal is blessed with rich water resources which have been providing important services (like drinking water source, generation of hydropower, irrigation, aquaculture and recreation) but due to weak implementation of pollution law and poor waste management strategy, freshwater resources are fast degrading.

The study area, Phewa Lake is the second largest lake and one of the main tourist destinations of Nepal. The panoramic view of Manaslu and Annapurna Mountain range and the refection of Machhapuchhre Mountain on the lake attracts tourist. The lakeshore is encroached by hotels and restaurants to capture the scenic beauty of the lake which has increased the pollution load of the lake. Till date no study on microplastic has been reported previously from the proposed study area. Therefore, the objective of this study was to compare the microplastic concentration in different seasons for Phewa Lake with regards to surface water. Thus, this study will bridge the gap to generate abundance and spatial distribution of microplastic from lake surface water for the first time. Further, this study will provide a baseline data on microplastic so the local authority could take action to protect the lake ecosystem before it is too late.

\section{Materials And Methods}

\subsection{Study area and sample collection}

Pokhara valley consists of nine lakes among which Phewa Lake is the largest in lake cluster. Its elevation ranges from $763 \mathrm{~m}$ to $2482 \mathrm{~m}$ (MoFE, 2018). The area of Phewa Lake covers $5.72 \mathrm{~km}^{2}$ with $122.53 \mathrm{~km}^{2}$ as the watershed region. The average depth of the lake is $8.6 \mathrm{~m}$ and maximum depth recorded as $23.5 \mathrm{~m}$ (Gurung et al., 2010). Phewa Lake is fed by Harpan Khola (stream), the main inlet of water to lake whereas at the outlet a dam is situated through which the water flows out. The lake has multipurpose use such as drinking water source, fishery and cage culture, irrigation, hydropower generation and boating. However, the lake is threatened from siltation, pollution from nearby city area and eutrophication by water hyacinth (MoFE, 2018).

Surface water samples were collected in the beginning of February, 2021 for winter season and in third week of July, 2021 for rainy season. A total of 16 sampling site were located by global positioning system (GPS) for equal distribution of the lake area (Fig. 1). The sites were divided into 8 sections as inlet 
and outlet area of the lake, dense, moderate and less populated area, center lake, temple area and mixing area where drainage from city is discharged. At each location, $5 \mathrm{~L}$ of surface water $(0-20 \mathrm{~cm}$ in depth) were collected by using bucket and was filtered through a $75 \mu \mathrm{m}$ sieve on site. The filter materials on the sieve were carefully transferred into the bottle (Mao et al., 2020) using 18.2 M $\Omega$ water (Millipore, Milli-Q). At each site 2 replicates of sample were collected and was stored at $4{ }^{0} \mathrm{C}$ before analysis. Furthermore, 1 $L$ of surface water were collected from each site to measure the water quality.

\subsection{Extraction of microplastic from water sample}

Extraction of microplastic from the surface water were performed with reference to National Oceanic and Atmospheric Administration (NAOO) (Masura et al., 2015) with slight modification. Briefly, the water sample were treated with $20 \mathrm{~mL}$ of $30 \% \mathrm{H}_{2} \mathrm{O}_{2}$ and $20 \mathrm{~mL} \mathrm{Fe}$ (II) solution as a catalyst to degrade the organic matter. After about 5 minutes it was heated on hot plate at $50{ }^{\circ} \mathrm{C}$ until it boils and kept for additional 15 minutes. Then, the digested sample was filtered through $1 \mathrm{~mm}$ sieve. The filtrate collected in a beaker was again carefully filtered through $47 \mathrm{~mm}$ diameter glass microfiber filter (Whatman $\mathrm{GF} / \mathrm{C}^{\mathrm{TM}}$ ) under a vacuum. The beaker was rinsed 2-3 times with Milli-Q water to ensure complete removal of microplastic. The filter paper was immediately kept in a clean petri dish and dried at room temperature for further examination (Yuan et al., 2019). If any microplastic was visible in the sieve it was picked with tweezer washed and kept in petri dish for visual identification separately.

\subsection{Identification of microplastic}

The petri dish along with filters were visually inspected under a stereomicroscope (SZ2-ILST, Olympus, Japan) at 40x magnification. Microplastic were identified according to their morphological characteristic into shape and color. Based on their shape microplastic were divided into 4 categories such as film, fiber/line, foam and fragment (Liu et al., 2019). Criteria described by Hidalgo-Ruz et al. (2012) were followed to identify microplastic in addition, hot needle test was done to confirm whether the suspected particles were plastic or non-plastic (De Witte et al., 2014). Plastic piece melted when a very hot needle was brought in contact if the sample piece under examination was plastic. This test was carried out due to small size of the collected microplastic. Number, shape and color were also recorded for each microplastic.

\subsection{Control of contamination}

Preventive measures were taken during sampling and laboratory analysis to avoid possible contamination. Cotton laboratory coat and nitrile gloves were worn during sampling and processing of the sample. Sample processing was conducted on the laminar flow hood, which was frequently cleaned with $75 \%$ ethanol. As far as possible glassware was used in the laboratory and before use it was rinsed with Milli Q water. Samples and glassware were covered with aluminum foil to minimize contamination during sample processing. After filtration, filter paper was immediately kept inside petri dish to avoid contamination. To find out air borne contamination, filter paper was first examined under 
stereomicroscope and then kept open on petri dish in the working environment for 24 hours. Results indicated negligible amount of contamination. Field blanks were also conducted.

\subsection{Data Analysis}

The mean abundance and standard deviation of microplastic were measured at different areas. The abundance of microplastic was expressed as the number of particles/L. The distribution of abundance according to different color and type of microplastic were also expressed. To test the significance difference among the various section of the lake, first the normality and homogeneity test was done using Shapiro-Wilk test for normality and Levene's test for homogeneity. Since the data did not follow the normality and homogeneity, Kruskall-Wallis $\mathrm{H}$ test was adopted to test the significance abundance among the different sections. Similarly, Dunn-Bonferroni post hoc test was used for comparison of different pairs. To test the significance difference of mean abundance between two seasons students' $t$ test was adopted.

\section{Results And Discussion}

\subsection{Abundance and spatial distribution of microplastic in Phewa Lake.}

Microplastic were present in all surface water collected from 16 sampling locations of Phewa Lake for winter and rainy seasons. The concentration of microplastic range from 0.8 - 8 particles $/ L$ for winter season and 0.4-2.8 particles/L for rainy season. The mean concentration of microplastic in rainy season (1.51 particles/L) was significantly lower than in winter season (2.96 particles/L) with $t=4.687(p<0.01)$. This could be due to recent flood that occurred before the sampling event which might have washed much of the microplastic from the surface water. For comparative study, the freshwater lake that expressed the abundance of microplastic as items/L were selected. This result showed that Phewa Lake has twice as much microplastic load than Rawal Lake, Pakistan (1.42 items/L) in winter season (Irfan et al., 2020) and almost equal amount of microplastic load in rainy season. Similarly, Red Hills Lake, India (Gopinath et al., 2020) has nearly two times more microplastic concentration (5.9 items/L) than Phewa Lake in winter season. Urban sewage drainage, solid waste disposal, runoff from agricultural land, laundry activities are the sources of contaminations of Phewa Lake (Pokharel, 2009) which may be loaded with microplastic. Fishery is another source of microplastic to the lake.

The whole lake was divided into 8 sections as inlet (IN-S1), outlet (OU-S2), mixing area (MI-S3), temple area (TE-S4), dense populated area (DE-S5-S8), moderate populated area (MO-S9-S10), less populated area (LE-S11-S12) and center lake area (CL-S13-S16). To find out the significance of abundance in different sections of the lake, Kruskall-Wallis $\mathrm{H}$ test was adopted. It was found that the average abundance of microplastic in different sections was significantly different $(\mathrm{H}=18.727$ with $p<0.01)$ for winter season while it was not significantly different in rainy season $(\mathrm{H}=13.825 p=0.054)$. Further to confirm which pair had a significance difference in winter season, Dunn-Bonferroni post hoc test was 
adopted (Table. S1). The result showed that there was a significance between the mean abundance of dense populated area with center lake area $(p<0.01)$ and outlet with center lake area $(p<0.1)$. Both the sections of lake (DE-S5-S8 and OU-S2) have more anthropogenic activities resulting high microplastic abundance than other sections of the lake.

In winter season, the lowest mean abundance of microplastic was found at the center lake area (1.375 \pm 0.494 items/L) where human activities are negligible followed by less populated area (mean $=2.15 \pm$ 0.640 items $/ L$ ) as shown in Table 1. This section is located on southern side of the lake which is covered by forest area with sparse rural settlement. Similarly, at the lake outlet mean microplastic concentration was found to be highest $(5.3 \pm 0.989$ items/L). This is probably due to direct discharge of untreated sewage from urban areas near the outlet of the lake and also by Phikre Khola which drains huge load of sewage and solid waste close by the outlet of Phewa Lake. Likewise, wind may have also transferred microplastic from nearby residential area (Liu et al., 2019). Hence, this could be the reason from higher concentration of microplastic at the dam outlet of Lake. Irfan et al. (2020) reported similar finding of Rawal Lake where the concentration of microplastic was highest at the outlet. Jian et al. (2020), Gopinath et al. (2020) and Jiang et al. (2018) also noted higher microplastic concentration at the lake outlet compared to the other area of the lake. Likewise for rainy season a slight variation in the mean concentration of microplastic were observed than in winter season in different location of lake (Table 1). Temple area (TE-S4) which lies in the center of the lake at southeast site was found to have the lowest concentration of microplastic. This could be due to closed down of temple area as a result of COVID pandemic. Studies have shown that the concentration of microplastic is related with anthropogenic factors such as density of population and the land use pattern (Cole et al., 2011; Hendrickson et al., 2018). Hence, dense population section of the lake has three times high microplastic concentration than the center lake area as this section of the lake is surrounded by hotels and restaurants which is one of the main tourist hub. In rainy season, the concentration of the microplastic in dense population section of the lake was reduced as all the hotels and restaurants around the lake surrounding were closed due to lockdown from summer season to the beginning of rainy season. Therefore, this study supports that densely populated locality and residential area close by the lake has high microplastic concentration (Xiong et al., 2018). Similarly, the highest mean abundance of microplastic concentration in rainy season was recorded in mixing area (MI-S3) which may be linked with direct discharge of untreated domestic effluent and surface run-off carrying microplastic from road side by Phikre Khola which drains into Phewa Lake at this section of the Lake. Field observation and lab analysis further strengthen that the sources of microplastic in the Phewa Lake is due to sewage and drainage discharge near the dam outlet, dry deposition and unmanaged sewage flow from hotels and restaurants surroundings the lake, fishing and fish cage culture, laundry activities, tourism and agricultural run-off from nearby land. Dry picnic with friends and families around the periphery of Phewa Lake is another potential source of micoplastic pollution to the lake. 
Table 1

Area wise distribution of microplastic (particles/L)

\begin{tabular}{|lllll|}
\hline & Winter season & \multicolumn{3}{c|}{ Rainy season } \\
\hline Area-Code & Mean & SD & Mean & SD \\
\hline DE-S5-S8 & 4.63 & 2.10 & 1.68 & 0.41 \\
MD-S9-S10 & 2.95 & 1.04 & 1.90 & 0.89 \\
LE-S11-S12 & 2.15 & 0.64 & 1.35 & 0.30 \\
CL-S13-S16 & 1.38 & 0.49 & 1.03 & 0.41 \\
\hline TE-S4 & 2.40 & 0.28 & 1.00 & 0.85 \\
\hline OU-S2 & 4.90 & 1.56 & 1.60 & 0.28 \\
\hline MI-S3 & 2.40 & 0.00 & 2.70 & 0.14 \\
\hline IN-S1 & 3.50 & 3.25 & 1.60 & 0.28 \\
\hline Total & 2.96 & 1.83 & 1.51 & 0.62 \\
\hline
\end{tabular}

\subsection{Morphological characterization of microplastic}

Photographs of typical microplastic items observed in surface water of Phewa Lake is given in Fig. 2. Fibers, film and fragments were the type of microplastic identified from Phewa Lake in winter season whereas foam was also detected in rainy season Fig. 3. Fibers were the most dominant shape for both season accounting for $93.04 \%$ and $96.69 \%$ of the total microplastic observed in lake surface water for winter and rainy season respectively. This result was similar with previous freshwater studies like 20 major lake, China (52.9 - 95.6\%) (Wang et al., 2017), Taihu Lake, China (48 - 84\%) (Su et al., 2016), Dongting Lake Chain (12.17 - 77.42\%) (Jiang et al., 2018), Lake Kallaveshi, Finland (64\%) (Uurasjarvi et al., 2020), Lake Naivasha, Kenya (81\%) (Migwi et al., 2020) which also reported surface water dominated by fibers. Therefore fibers in the lake surface water may be associated with domestic wastewater (Browne et al., 2011) which is directly discharged into the lake, ageing fishing rod and nets (Yuan et al., 2019) and washing clothes (Browne et al., 2011) at the lake bank. However, further extensive research are required to disclose the dominance of microplastic fibers in the lake system. Films and fragments are produced by the fragmentation of plastic debris thrown away by tourist and local residents (Eerkes-Medrano et al., 2015), which was also confirmed by field observations as plastic waste were littered around the periphery of the lake. Foam probably originated from thermocol box which are used for fish storage and transportation.

Microplastic were identified and classified into seven colors in winter season and eight colors in rainy season as shown in Fig. 4. Transparent was the predominant color of microplastic for both seasons accounting for $40.51 \%$ and $31.41 \%$ in winter and rainy season respectively. In winter season, all the microplastic detected were found to be less than $1 \mathrm{~mm}$ in size from sixteen sampling locations. Whereas 
in rainy season, $98.78 \%$ of the microplastic were of size less than $1 \mathrm{~mm}$ and $1.2 \%$ were of size $1-5 \mathrm{~mm}$. Color and size of microplastic is linked with ingestion by aquatic organism if it resembles prey (Wright et al., 2013)

\section{Conclusion}

This study determines the first report on microplastic occurrence in lake system of Nepal and fill the gap by providing data on microplastic pollution. This further attracts researchers to explore this emerging environmental pollutant with the limited resources available in the country as water resources acts as a driving force for overall development and economic progress of the country. Phewa Lake serves as an important tourist site. Therefore, high concentration of microplastic in surface water is raising an ecological concern that must be addressed. Large number of hotels, resorts and restaurants around the lakeside, direct disposal of drainage into the lake, activities like washing clothes, fishing, tourism and recreation are the cause of microplastic concentration of Phewa Lake. Future research should focus to assess the risk of microplastic on aquatic organism to protect the lake diversity.

\section{Declarations}

\section{Ethics approval and consent to participate}

Not Applicable

\section{Consent for publication}

Not Applicable

\section{Availability of data and materials}

The datasets used and/or analyzed during the current study are available from the corresponding author on reasonable request.

\section{Competing interest}

The authors declare that they have no competing interests.

\section{Funding}

Partial.

\section{Authors' contributions}


Conceptualization, Visualization, Writing-Original draft was done by Rajeshwori Malla-Pradhan. WritingReviewing and Editing was done by Thitipone Suwunwong and Tista Prasai Joshi. Supervision and validation was done by Khamphe Phoungthong. Data curation and Formal analysis was performed by Bijay Lal Pradhan. All authors read and approved the final manuscript.

\section{Acknowledgment}

This research was supported from Graduate School, Prince of Songkla University, Thailand for which the authors highly acknowledge. We extend our gratitude to Nepal Academy of Science and Technology (NAST) for providing laboratory and facilitate to conduct our research work.

\section{References}

1. Akdogan, Z., \& Guven, B. (2019). Microplastics in the environment: A critical review of current understanding and identification of future research needs. Environ Pollut, 254(Pt A), 113011. https://doi.org/10.1016/j.envpol.2019.113011

2. Allen, S., Allen, D., Phoenix, V. R., Le Roux, G., Jiménez, P. D., Simonneau, A., Binet, S., \& Galop, D. (2019). Atmospheric transport and deposition of microplastics in a remote mountain catchment. Nature Geoscience, 12(5), 339-344.

3. Au, S. Y., Bruce, T. F., Bridges, W. C., \& Klaine, S. J. (2015). Responses of Hyalella azteca to acute and chronic microplastic exposures. Environ Toxicol Chem, 34(11), 2564-

2572. https://doi.org/10.1002/etc.3093

4. Avio, C. G., Gorbi, S., Milan, M., Benedetti, M., Fattorini, D., d'Errico, G., Pauletto, M., Bargelloni, L., \& Regoli, F. (2015). Pollutants bioavailability and toxicological risk from microplastics to marine mussels. Environ Pollut, 198, 211-222. https://doi.org/10.1016/j.envpol.2014.12.021

5. Barrett, J., Chase, Z., Zhang, J., Holl, M. M. B., Willis, K., Williams, A., Hardesty, B. D., \& Wilcox, C. (2020). Microplastic pollution in deep-sea sediments from the great Australian Bight. Front Mar Sci , 7, 808. https://doi.org/10.3389/fmars.2020.576170

6. Betts, K. (2008). Why small plastic particles may pose a big problem in the oceans. Environ Sci Technol, 42(24), 8995. https://doi.org/10.1021/es802970v

7. Brennecke, D., Duarte, B., Paiva, F., Caçador, I., \& Canning-Clode, J. (2016). Microplastics as vector for heavy metal contamination from the marine environment. Estuar Coast Shelf Sci 178, 189-195.

8. Browne, M. A., Crump, P., Niven, S. J., Teuten, E., Tonkin, A., Galloway, T., \& Thompson, R. (2011). Accumulation of microplastic on shorelines woldwide: sources and sinks. Environ Sci Technol, 45(21), 9175-9179. https://doi.org/10.1021/es201811s

9. Campanale, C., Savino, I., Pojar, I., Massarelli, C., \& Uricchio, V. F. (2020). A Practical overview of methodologies for sampling and analysis of microplastics in riverine environments.

Sustainability, 12(17), 6755. https://doi.org/10.3390/su12176755 
10. Cole, M., Lindeque, P., Fileman, E., Halsband, C., \& Galloway, T. S. (2015). The impact of polystyrene microplastics on feeding, function and fecundity in the marine copepod Calanus helgolandicus. Environ Sci Technol, 49(2), 1130-1137. https://doi.org/10.1021/es504525u

11. Cole, M., Lindeque, P., Halsband, C., \& Galloway, T. S. (2011). Microplastics as contaminants in the marine environment: a review. Mar Pollut Bull, 62(12), 2588-

2597. https://doi.org/10.1016/j.marpolbul.2011.09.025

12. De Witte, B., Devriese, L., Bekaert, K., Hoffman, S., Vandermeersch, G., Cooreman, K., \& Robbens, J. (2014). Quality assessment of the blue mussel (Mytilus edulis): comparison between commercial and wild types. Mar Pollut Bull, 85(1), 146-155. https://doi.org/10.1016/j.marpolbul.2014.06.006

13. Eerkes-Medrano, D., Thompson, R. C., \& Aldridge, D. C. (2015). Microplastics in freshwater systems: a review of the emerging threats, identification of knowledge gaps and prioritisation of research needs. Water Res, 75, 63-82. https://doi.org/10.1016/j.watres.2015.02.012

14. Eriksen, M., Mason, S., Wilson, S., Box, C., Zellers, A., Edwards, W., Farley, H., \& Amato, S. (2013). Microplastic pollution in the surface waters of the Laurentian Great Lakes. Mar Pollut Bull, 77(1-2), 177-182. https://doi.org/10.1016/j.marpolbul.2013.10.007

15. Galgani, F., Hanke, G., \& Maes, T. (2015). Global distribution, composition and abundance of marine litter. Marine anthropogenic litter (pp. 29-56). Springer, Cham. https://doi.org/10.1007/978-3-31916510-3_2

16. Gambardella, C., Morgana, S., Ferrando, S., Bramini, M., Piazza, V., Costa, E., Garaventa, F., \& Faimali, M. (2017). Effects of polystyrene microbeads in marine planktonic crustaceans. Ecotoxicol Environ Saf, 145, 250-257. https://doi.org/10.1016/j.ecoenv.2017.07.036

17. Gasperi, J., Dris, R., Bonin, T., Rocher, V., \& Tassin, B. (2014). Assessment of floating plastic debris in surface water along the Seine River. Environ Pollut, 195, 163-

166. https://doi.org/10.1016/j.envpol.2014.09.001

18. Geyer, R., Jambeck, J. R., \& Law, K. L. (2017). Production, use, and fate of all plastics ever made. Sci $A d v, 3(7)$, e1700782. https://doi.org/10.1126/sciadv.1700782

19. Gopinath, K., Seshachalam, S., Neelavannan, K., Anburaj, V., Rachel, M., Ravi, S., Bharath, M., \& Achyuthan, H. (2020). Quantification of microplastic in Red Hills Lake of Chennai city, Tamil Nadu, India. Environ Sci Pollut Res Int, 27(26), 33297-33306. https://doi.org/10.1007/s11356-020-09622-2

20. Green, D. S. (2016). Effects of microplastics on European flat oysters, Ostrea edulis and their associated benthic communities. Environ Pollut, 216, 95103. https://doi.org/10.1016/j.envpol.2016.05.043

21. Gurung, T. B., Dhakal, R. P., Husen, M. A., \& Jones, J. R. (2010). Abundance and nutrient limiting growth rate of heterotrophic bacterio-plankton in Himalayan foot hill Lake Phewa, Nepal. Lakes \& Reservoirs: Research \& Management, 15(1), 53-61. https://doi.org/10.1111/j.14401770.2010.00422.x

22. Hendrickson, E., Minor, E. C., \& Schreiner, K. (2018). Microplastic abundance and composition in western Lake Superior as determined via microscopy, Pyr-GC/MS, and FTIR. Environ Sci 
Technol, 52(4), 1787-1796.

23. Hidalgo-Ruz, V., Gutow, L., Thompson, R. C., \& Thiel, M. (2012). Microplastics in the marine environment: a review of the methods used for identification and quantification. Environ Sci Technol, 46(6), 3060-3075. https://doi.org/10.1021/es2031505

24. Irfan, T., Khalid, S., Taneez, M., \& Hashmi, M. Z. (2020). Plastic driven pollution in Pakistan: the first evidence of environmental exposure to microplastic in sediments and water of Rawal Lake. Environ Sci Pollut Res Int, 27(13), 15083-15092. https://doi.org/10.1007/s11356-020-07833-1

25. Jeong, C. B., Kang, H. M., Lee, M. C., Kim, D. H., Han, J., Hwang, D. S., Souissi, S., Lee, S. J., Shin, K. H., Park, H. G., \& Lee, J. S. (2017). Adverse effects of microplastics and oxidative stress-induced MAPK/Nrf2 pathway-mediated defense mechanisms in the marine copepod Paracyclopina nana. Sci Rep, 7, 41323. https://doi.org/10.1038/srep41323

26. Jian, M., Zhang, Y., Yang, W., Zhou, L., Liu, S., \& Xu, E. G. (2020). Occurrence and distribution of microplastics in China's largest freshwater lake system. Chemosphere, 261, 128186. https://doi.org/10.1016/j.chemosphere.2020.128186

27. Jiang, C., Yin, L., Wen, X., Du, C., Wu, L., Long, Y., Liu, Y., Ma, Y., Yin, Q., Zhou, Z., \& Pan, H. (2018). Microplastics in Sediment and Surface Water of West Dongting Lake and South Dongting Lake: Abundance, Source and Composition. Int J Environ Res Public Health, 15(10). https://doi.org/10.3390/ijerph15102164

28. Koelmans, B., Pahl, S., Backhaus, T., Bessa, F., van Calster, G., Contzen, N., Cronin, R., Galloway, T., Hart, A., \& Henderson, L. (2019). A scientific perspective on microplastics in nature and society. SAPEA. https://doi.org/10.26356/microplastics

29. Liu, S., Jian, M., Zhou, L., \& Li, W. (2019). Distribution and characteristics of microplastics in the sediments of Poyang Lake, China. Water Sci Technol, 79(10), 1868-

1877. https://doi.org/10.2166/wst.2019.185

30. Mao, R., Hu, Y., Zhang, S., Wu, R., \& Guo, X. (2020). Microplastics in the surface water of Wuliangsuhai Lake, northern China. Sci Total Environ, 723,

137820. https://doi.org/10.1016/j.scitotenv.2020.137820

31. Masura, J., Baker, J., Foster, G., \& Arthur, C. (2015). Laboratory methods for the analysis of microplastics in the marine environment: recommendations for quantifying synthetic particles in waters and sediments. Siver Spring, MD, NOAA Marine Debris Division. http://dx.doi.org/10.25607/OBP-604

32. Migwi, F. K., Ogunah, J. A., \& Kiratu, J. M. (2020). Occurrence and spatial distribution of microplastics in the surface waters of lake Naivasha, Kenya. Environ Toxicol Chem, 39(4), 765-

774. https://doi.org/10.1002/etc.4677

33. Ministry of Forest and Environment. (2018). Integrated Lake Basin Management Plan of Lake Cluster of Pokhara Valley, Nepal (2018-2023). MoFE, Nepal.

34. Negrete Velasco, A. d. J., Rard, L., Blois, W., Lebrun, D., Lebrun, F., Pothe, F., \& Stoll, S. (2020). Microplastic and Fibre Contamination in a Remote Mountain Lake in Switzerland. Water, 12(9), 
2410.

35. Parashar, N., \& Hait, S. (2021). Plastics in the time of COVID-19 pandemic: Protector or polluter? Sci Total Environ, 759, 144274. https://doi.org/10.1016/j.scitotenv.2020.144274

36. Plastics Europe. (2020). Plastics - the Facts 2020: An analysis of European plastics production, demand and waste data. https://www.plasticseurope.org/en/resources/publications/4312-plasticsfacts-2020

37. Pokharel, S. (2009). Lessons from Nepal on Developing a Strategic Plan for the Integrated Lake Basin Management Conservation of Phewa Lake of Pokhara, Nepal. Sigha University and ILEC.

38. Silva, A. L. P., Prata, J. C., Walker, T. R., Duarte, A. C., Ouyang, W., Barcelò, D., \& Rocha-Santos, T. (2020). Increased plastic pollution due to COVID-19 pandemic: Challenges and recommendations. Chem Eng J, 126683.

39. Su, L., Xue, Y., Li, L., Yang, D., Kolandhasamy, P., Li, D., \& Shi, H. (2016). Microplastics in Taihu Lake, China. Environ Pollut, 216, 711-719. https://doi.org/10.1016/j.envpol.2016.06.036

40. Sussarellu, R., Suquet, M., Thomas, Y., Lambert, C., Fabioux, C., Pernet, M. E., Le Goic, N., Quillien, V., Mingant, C., Epelboin, Y., Corporeau, C., Guyomarch, J., Robbens, J., Paul-Pont, I., Soudant, P., \& Huvet, A. (2016). Oyster reproduction is affected by exposure to polystyrene microplastics. Proc Natl Acad Sci U S A, 113(9), 2430-2435. https://doi.org/10.1073/pnas.1519019113

41. Thompson, R. C., Olsen, Y., Mitchell, R. P., Davis, A., Rowland, S. J., John, A. W., McGonigle, D., \& Russell, A. E. (2004). Lost at sea: where is all the plastic? Science, 304(5672), 838. https://doi.org/10.1126/science.1094559

42. United Nations Environmental Program. (2018). Mapping of global plastics value chain and plastics losses to the environment: with a particular focus on marine environment. M. W. Ryberg, A. Laurent, \& M. Hauschild.

43. United Nations Environmental Program. (2021, 30 March). Plastic pollution disproportionately hitting marginalized groups, UN environment report finds. UN News: Global perspective Human stories. https://news.un.org/en/story/2021/03/1088712

44. Uurasjarvi, E., Hartikainen, S., Setala, O., Lehtiniemi, M., \& Koistinen, A. (2020). Microplastic concentrations, size distribution, and polymer types in the surface waters of a northern European lake. Water Environ Res, 92(1), 149-156. https://doi.org/10.1002/wer.1229

45. Wang, W., Ndungu, A. W., Li, Z., \& Wang, J. (2017). Microplastics pollution in inland freshwaters of China: A case study in urban surface waters of Wuhan, China. Sci Total Environ, 575, 13691374. https://doi.org/10.1016/j.scitotenv.2016.09.213

46. Watts, A. J., Urbina, M. A., Corr, S., Lewis, C., \& Galloway, T. S. (2015). Ingestion of Plastic Microfibers by the Crab Carcinus maenas and Its Effect on Food Consumption and Energy Balance. Environ Sci Technol, 49(24), 14597-14604. https://doi.org/10.1021/acs.est.5b04026

47. Wright, S. L., Thompson, R. C., \& Galloway, T. S. (2013). The physical impacts of microplastics on marine organisms: a review. Environ Pollut, 178, 483-

492. https://doi.org/10.1016/j.envpol.2013.02.031 
48. Xiong, X., Zhang, K., Chen, X., Shi, H., Luo, Z., \& Wu, C. (2018). Sources and distribution of microplastics in China's largest inland lake - Qinghai Lake. Environ Pollut, 235, 899906. https://doi.org/10.1016/j.envpol.2017.12.081

49. Yuan, W., Liu, X., Wang, W., Di, M., \& Wang, J. (2019). Microplastic abundance, distribution and composition in water, sediments, and wild fish from Poyang Lake, China. Ecotoxicol Environ Saf, 170, 180-187. https://doi.org/10.1016/j.ecoenv.2018.11.126

\section{Figures}

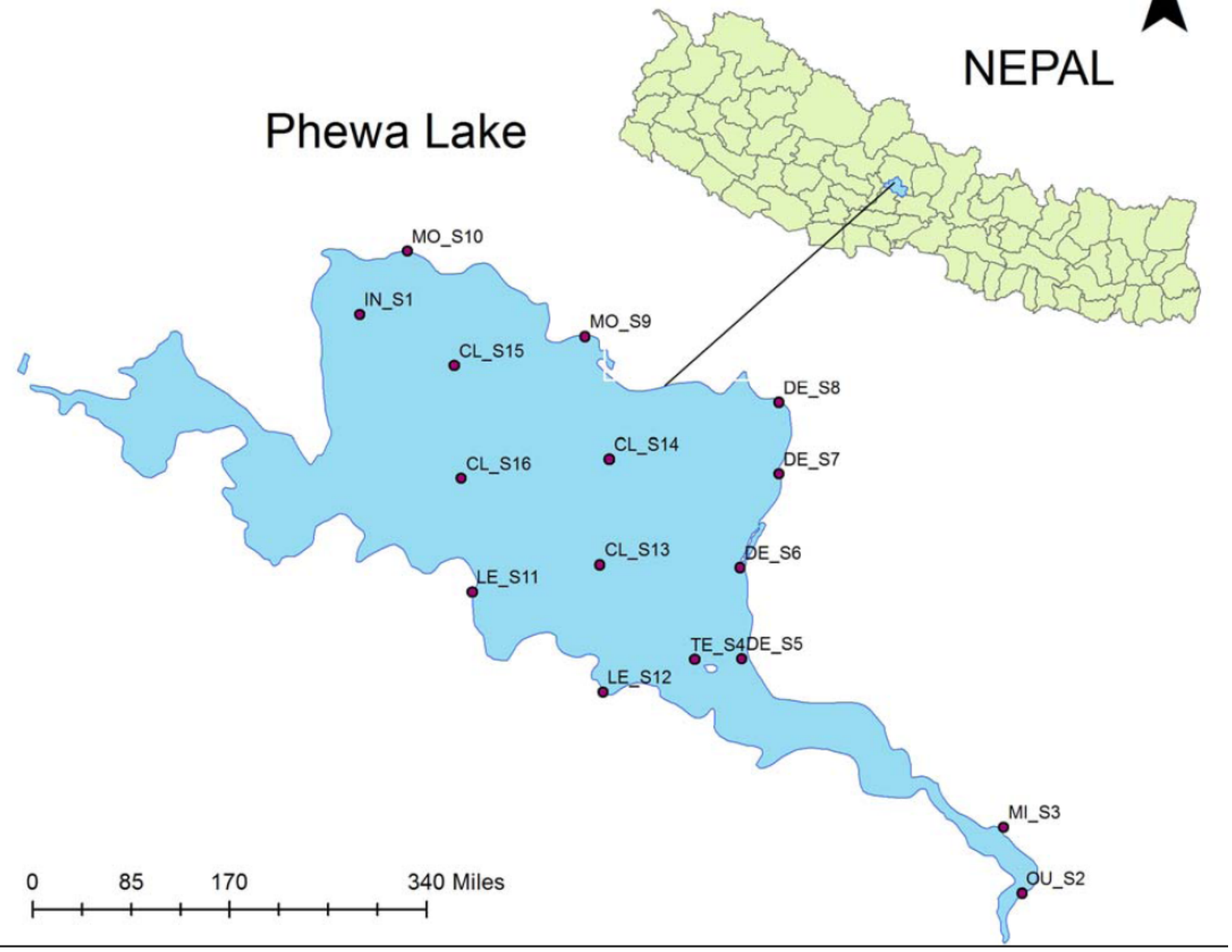

Figure 1

Sampling points of study area 


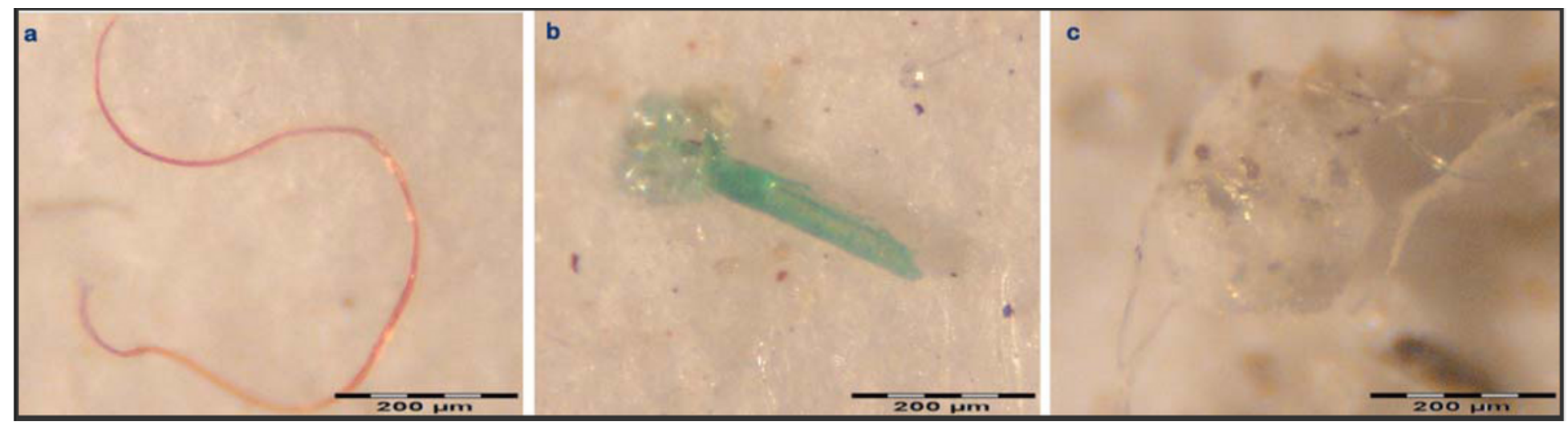

Figure 2

Photographs of typical microplastic found in surface water of Phewa Lake (a) fiber, ( b) fragment (after melt test) and (c) film.

\section{$\mathbb{E}$ Winter : Rainy}

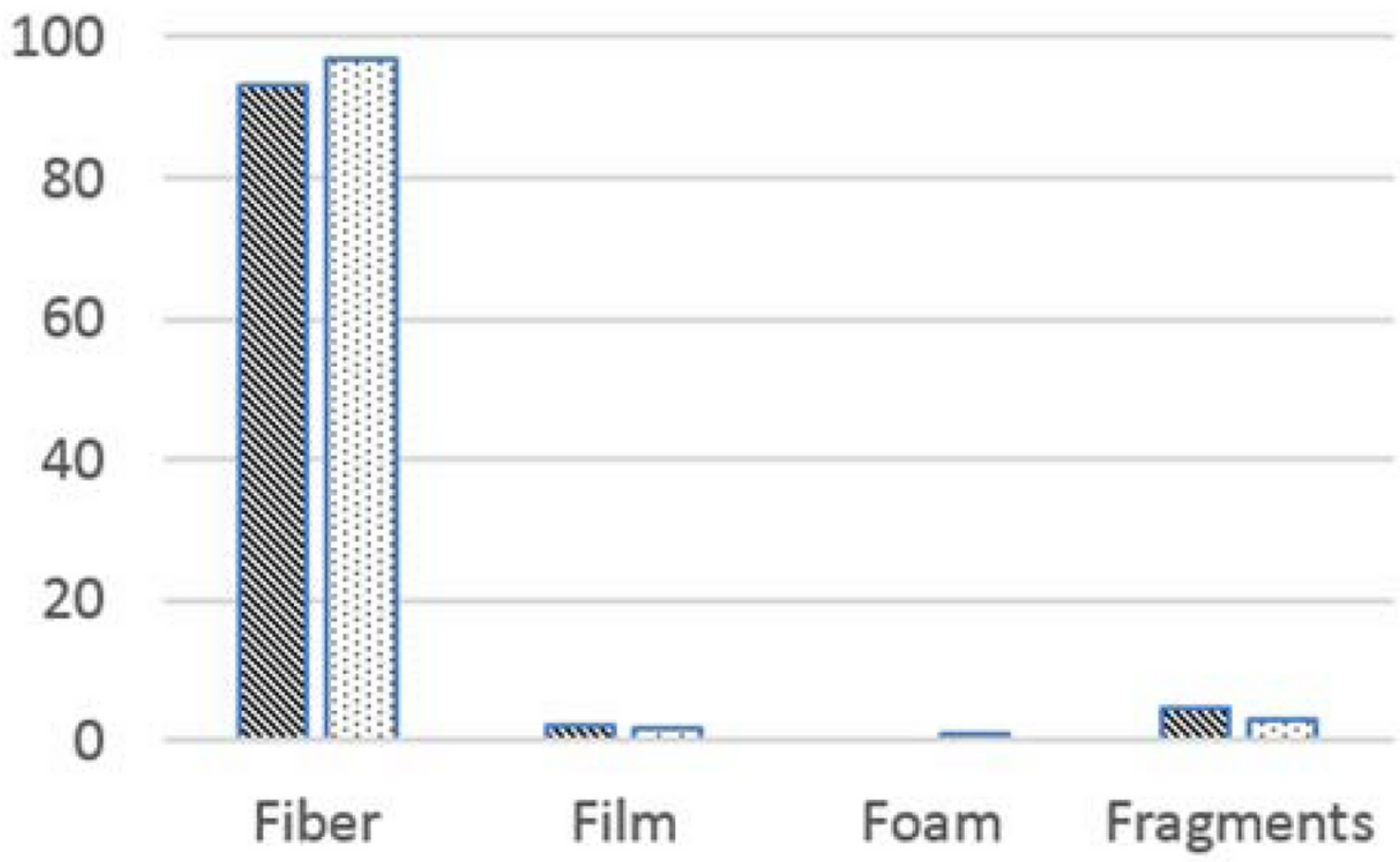

\section{Figure 3}

Percentage distribution of microplastic by shape in Phewa Lake. 


\section{$\mathbb{E}$ Winter 圆 Rainy}

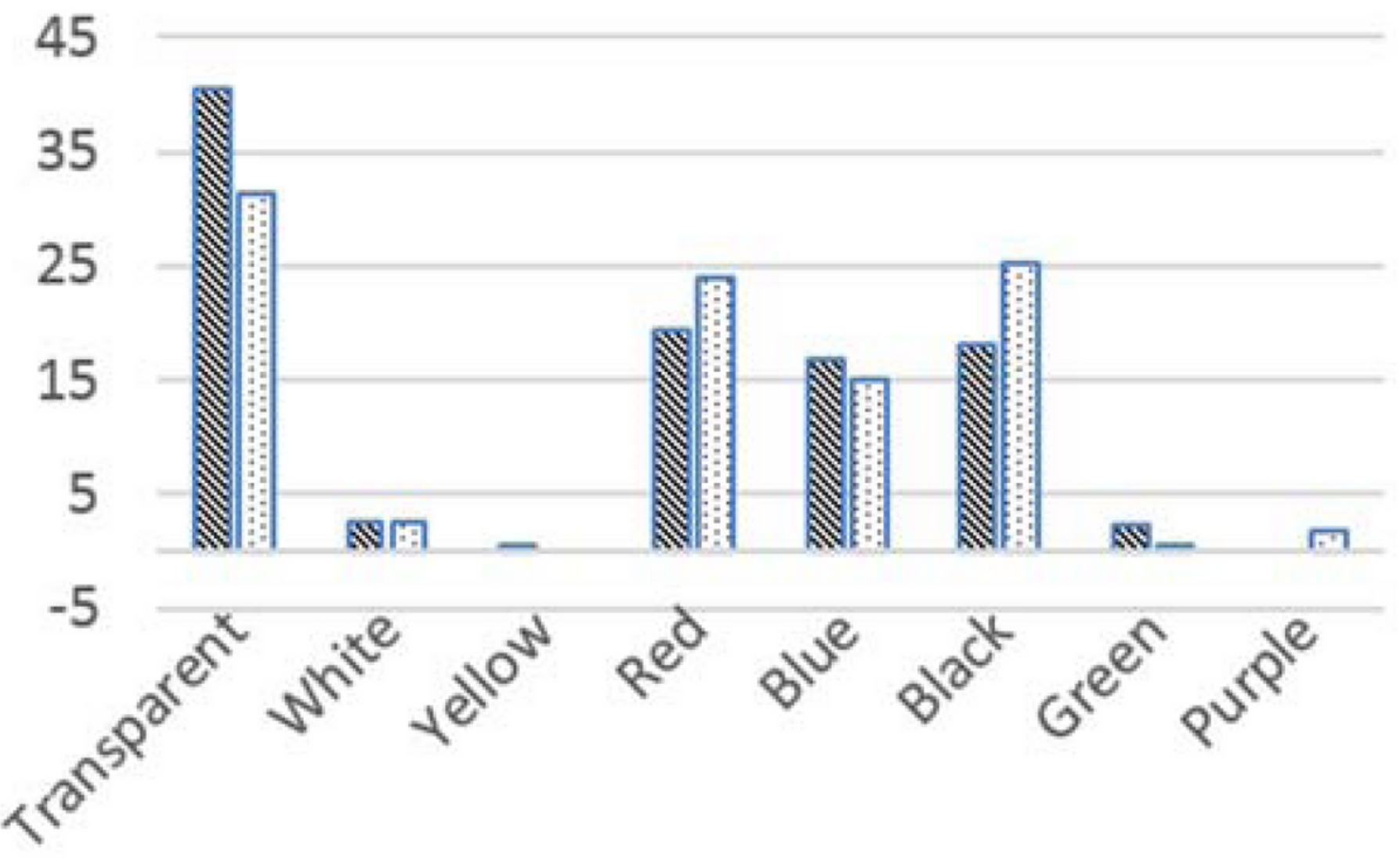

\section{Figure 4}

Percentage distribution of microplastic by color in Phewa Lake

\section{Supplementary Files}

This is a list of supplementary files associated with this preprint. Click to download.

- SI1.pdf 